\title{
LIMITED FLOW CHARACTERISTICS OF SAND WITH FINES UNDER CYCLIC LOADING
}

\author{
S.R. Lo ${ }^{\text {a) }}$, Md. Mizanur Rahman ${ }^{\text {b) }}$ and D. Bobei ${ }^{\text {c) }}$
}

\author{
a), b): University of New South Wales, ADFA Campus, Canberra, ACT 2600, Australia \\ Tel: 61-2-62688340; fax: 61-2-62688337; email: r.1o@adfa.edu.au \\ c): $\quad$ Sinclair Knight Merz Pty Ltd, Australia \\ Tel: +61 29928 2571; Fax: +61 29928 2510; Email: dbobei@skm.com.au
}


Special Issue on Disaster Mitigation and Rehabilitation

\begin{abstract}
:
Experimental studies on a sand with a well-graded low plasticity fines were conducted to study a number of issues related to limited flow. Cyclic behaviour in relation to instability and limited flow are compared with corresponding monotonic behaviour. A single set of rules for a range of fines contents was proposed to correlate cyclic and monotonic behaviour.
\end{abstract}

\title{
Key Words:
}

Instability, cyclic loading, fines, limited flow, strain softening 
Special Issue on Disaster Mitigation and Rehabilitation

\section{INTRODUCTION}

Significant progress has been made, since the 80 s, in linking liquefaction to instability; and as such the strain softening behaviour under monotonic undrained loading provides the key for understanding cyclic liquefaction behaviour. This has a significant bearing on disaster mitigation as liquefaction type failure can lead to significant loss in lives and properties. Mohamad and Dorby (1986) reported that the monotonic behaviour of soil should be considered in analyzing the undrained cyclic behaviour of saturated sand. Georgiannou et al. (1991) demonstrated that the monotonic bounding envelope of Ham river sand as determined in undrained loading was also applicable in determining cyclic response. Konrad (1993) found that the undrained peak strength envelope in the effective stress space could be used to define the triggering of strain softening in both monotonic and cyclic undrained loading. This envelope could be taken to be a single line for samples at similar void ratio. Yamamuro and Covert (2001) confirmed that cyclic liquefaction in loose Nevada sand with $40 \%$ silt was triggered by "crossing" the instability line. Vaid and Sivathayalan (2000) reported that strain softening under undrained cyclic loading occurred when the mobilized friction angle attained the value that triggered strain softening under static loading. Gennaro et al. (2004) suggested that the response in undrained monotonic shearing contributed to the prediction of undrained response in cyclic loading.

Based on the above studies, the conceptual framework for linking liquefaction under cyclic loading to static liquefaction is presented in Fig. 1. Unless stated otherwise to the contrary, shearing is performed under an undrained mode. In this framework liquefaction is a manifestation of instability and this is different from cyclic mobility. We can define an instability stress ratio, $\eta_{\mathrm{IS}}$, by the effective stress state at peak undrained strength under monotonic loading. When the effective stress state crosses the line

Field Code Changed

Field Code Changed

Field Code Changed

Field Code Changed

Field Code Changed

Formatted: Font: Italic 


\section{Special Issue on Disaster Mitigation and Rehabilitation}

defined by $\eta_{\mathrm{IS}}$ as a result of pore water pressure generation due to either monotonic or cyclic loading, instability will be triggered. It is evident from Fig. 1 that the deviator stress required to trigger instability under cyclic loading is less than that in monotonic loading. Furthermore, the effective stress path of monotonic loading defines the boundary of admissible stress state during cyclic loading.

However, experimental evidence directly verifying the above conceptual framework is relatively limited for sand with fines, although sandy deposits may contain certain amount of fines. In the case of limited flow, there is also the dilemma illustrated in Fig. 2. In monotonic loading, the deviatoric stress-strain curves is characterized by strain softening to the so-called quasi-steady state (QSS) and then followed by strain hardening. For a replicate soil element being brought to instability by cyclic loading, will there be a regain in stability when the soil is sheared, cyclically, beyond a condition that corresponds to the QSS point in monotonic loading? There is also the question about the influence of fines content on cyclic behaviour. For sand with a very low fines content, say less than or equal to $10 \%$, the concept of intergranular void ratio (Thevanayagam 1998) that treats fines as void spaces, is an adequate idealisation. This implies that, at such low fines content, the contribution of the fines to the force structure of the sand-fines mixture is negligible. However, the contribution of fines to the force structure of a sand-fines mixture increases with increasing fines content (Rahman and Lo 2008b; Rahman et al. 2008). This leads to the question of whether the influence of fines content needs to be factored into conceptual framework linking instability in monotonic and cyclic loading? To address the above issues, a series of monotonic and cyclic triaxial tests were conducted on a sand-fines mixture. The fines content covered by this study ranges from $0 \%$ to $20 \%$. Therefore, the findings of this study will apply to a range of fines contents. It is pertinent to note that the highest fines content of $20 \%$ is still less than 
Special Issue on Disaster Mitigation and Rehabilitation

the threshold value (Rahman and Lo 2008). Therefore, the "fines-in-sand" model would still apply (Chu and Leong 2002; Rahman and Lo 2007a; Rahman and Lo 2007b; Rahman et al. 2008). In this range of fines contents, the contribution of fines to the force structure will progressively increase with fines content but the overall matrix is still the host sand. The test results can be synthesized to investigate three issues. The first one is to examine whether limited flow characteristics were manifested in cyclic loading. The second one is to establish some linkages between monotonic and cyclic instability in the case of limited flow. This naturally leads to the last issue, the influence of fines content, if any, on the linkages between monotonic and cyclic behaviour.

\section{EXPERIMENTAL STUDY}

\subsection{Material Tested}

The sand-fines mixture was formed from a host sand, referred to as Sydney Sand, with controlled amounts of fines added to it. The host sand, i.e. Sydney sand, is a clean uniform size quartz sand (SP) with a mean size of $0.30 \mathrm{~mm}$ and it's index properties can be found in Lo et al. (1989). The fines was constituted from $2 / 3$ natural silt from the Majura River bank deposits and 1/3 commercial kaolin. The resultant fines is a wellgraded fines with a uniformity coefficient of 12.56 and a plasticity index of 11 (i.e. low plasticity). The grading curve of the fines is presented in Fig. 3. Controlled amount of fines was added to the host sand to achieve sand-fines mixtures of varying fines contents. The fines contents studied in this paper ranges from $0 \%$ (i.e. host sand only) to $20 \%$, and Deleted: can be Deleted: give Formatted: Font color: Dark Blue the "combined grading curves of the sand fines mixtures were also presented in Fig. 3.

Scanning Electronic Microscope (SEM) photographs of the sand and the fines were presented in Figs. 4a-b, whereas that of sand-fines mixture was presented in Fig. 5. A comparison of the SEM photos of the host sand (Fig. 4a) and sand-fines mixture (Fig. 


\section{Special Issue on Disaster Mitigation and Rehabilitation}

5) showed that the fabric of the sand-fines mixture conformed to that of a "fines-in-sand" model (Rahman and Lo 2008a; Rahman and Lo 2008b; Rahman et al. 2008). The SEM photos showed that the fines consist of angular particles with "spongy" balls and clusters on the surfaces of the angular particles (Fig. 4b). This will lead to a higher overall volumetric compressibility of the fines.

\subsection{Specimen Preparation}

A specimen was formed by a modified moist tamping method. A pre-determined quantity of moist soil was carefully placed and then tamped lightly into a prescribed thickness using a standardized plastic strip with a tamping area of $8.5 \times 20 \mathrm{~mm}$. A total of 10 layers were placed in forming a specimen with a dimension of $100 \mathrm{~mm}$ in both diameter and height. In this manner, the as-placed void ratio could be controlled tightly to a required value. Free ends with enlarged platens were used to minimize end restraint. This technique has been proven to be successful in achieving essentially uniform deformation for a range of soil type (Chu and Lo 1993; Lo and Chen 1999; Lo and Wardani 2002). Bedding and membrane penetration errors were reduced to an insignificant value by using the liquid rubber technique developed by Lo et al. (1989). Saturation was achieved by vacuum flushing with a low head followed by back pressure saturation. Details of the specimen preparation method are contained in Bobei ${ }_{4}(2004)$ and Rahman, Lo and Gnanendran (2008). It is pertinent to emphasize that specimens prepared by the above-mentioned technique showed essentially uniform deformation field even at high strain as illustrated in Fig. 6. This is essential as the focus of this experimental study is generally at the high strain spectrum. 
Special Issue on Disaster Mitigation and Rehabilitation

\subsection{Experiment procedures}

A schematic diagram of the experimental setup is shown in Fig. 7. A triaxial testing system with PC-controlled data logging and stress/strain control capabilities was used for this study. Axial load was applied by a force actuator located beneath the bottom platen but measured with an internal load cell located just above the top platen. The test results presented in this paper were all based on internal load cell measurements and would not be adversely affected by ram friction. The axial deformation was measured with a pair of internal LVDTs mounted directly across the platens plus an external LVDT. The former was used for axial deformation calculation during the early stage of shearing whereas the latter was used at large deformation. Cell pressure was controlled by a large capacity Digital Pressure Volume Controller (DPVC). The pore pressure line was connected to a small capacity DPVC which served two purposes: i) controlling back pressure and measurement of volume change in drained stage, and ii) ensuring nil volume change and measuring pore water generation in undrained shearing. Pressure transducers were mounted at both the top and bottom platens to enable verification of pore pressure equilibrium.

It is pertinent to note that in a monotonic test, the force actuator will be in a displacement controlled mode (at a rate of $0.03 \mathrm{~mm} / \mathrm{min}$ ) and hence any reduction of load (and deviator stress) with shearing could be clearly defined. In a cyclic loading test, a specimen was first brought to a static deviator stress in a displacement control mode, and

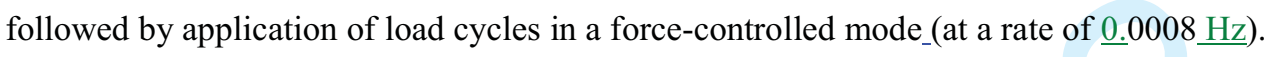
The force actuator was driven by a geared stepper motor, which is not a fast response system. This means that the actuator cannot apply a force exceeding the resistance of the specimen by driving the specimen to rapid acceleration. This attribute, plus having the force actuator located at the bottom of the loading train that had a mass of approximately 
Special Issue on Disaster Mitigation and Rehabilitation

$30 \mathrm{~kg}$, implies that the internal load cell at the top of the specimen can reliably give the

resistance provided by the specimen. When the specimen is brought to instability by cyclic loading with a prescribed peak deviator stress, the internal load cell will instead give the deviatoric resistance of the specimen, which is less than the prescribed peak deviator stress. Onset of instability is thus indicated by the deviator stress achieved (as inferred from internal load cell) being significantly less than the prescribed value (inferred from the command sent to force actuator).

\section{TESTING PROGRAM}

The testing program was designed to give pairs of tests, one for monotonic loading and the other one for cyclic loading. The void ratios of the tests in each test pair are very close. However, the void ratios of the six test pairs range from 0.569 to 0.850 . The testing program is presented in Table 1 , which contains 6 pairs of isotropically consolidated undrained tests. _ It covers the following spectrum of limited flow behaviour.

- significant strain softening to QSS followed by slight strain hardening,

- significant strain softening to QSS followed by significant strain hardening,

- slight strain softening to QSS followed by significant strain hardening.

A test is identified by a name in the format of "alphabet-xx-yy", where alphabet is either "M" for monotonic and " $\mathrm{C}$ " for cyclic, "xx" is the fines content in percentages, and "yy" is an additional reference number. 
Special Issue on Disaster Mitigation and Rehabilitation

\section{COMPARISON BETWEEN MONOTONIC AND CYCLIC BEHAVIOUR}

\subsection{Host sand}

A comparison between the monotonic and cyclic response of $0 \%$ fines content, i.e. host sand only, provide a benchmark for synthesizing the influence of fines content. Two such test pairs, are available for this comparison.

Deleted: in

\subsubsection{Test pair M-00-08 for monotonic loading and C-00-20 for cyclic loading.}

The comparison of undrained responses is presented in Fig. 8a-b, whereas the cyclic loadtime trace was plotted in Fig. 8c. The effective stress path (ESP) and deviatoric stressstrain curve of the monotonic test was typical limited flow behaviour, although the postQSS strain hardening was not rapid enough to mobilize a deviator stress higher than $q_{\text {IS }}$ before end of test, where $q_{\text {IS }}$ is the deviator stress at onset of instability which is also the maximum deviator stress attainable. The effective stress ratio at this state, denoted as $\eta_{\mathrm{IS}}$, can be represented by a dotted line in the $q-p^{\prime}$ space. This dotted line is referred to as the instability line.

The specimen for the cyclic test was first brought to a deviator stress as indicated Deleted: by point "A". Then two packets of cyclic load (of different prescribed peak deviator stress and load cycles) were prescribed. It is pertinent to re-iterate that the actuator is a slow response type and hence the actual peak deviator stress achieved (as recorded by the internal load cell) was limited by the resistance of the specimen. This means the prescribed peak deviator stress can only be realized if it was less than the available deviator resistance at the corresponding deviatoric strain.

The first packet of stress pulses consisted of 4 cycles with a prescribed $q_{\text {peak }}$ of $450 \mathrm{kPa}$, where $q_{\text {peak }}$ denotes peak deviator stress. However, the highest deviator stress realized in the first cyclic was at point " $\mathrm{B}$ " which had a value of $\sim 395 \mathrm{kPa}$. The deviator stress then reduced during unloading and with the loading phase tracing out the limited

Formatted: Font: Italic

Formatted: Font: Italic

Formatted: Font: Italic

Formatted: Font: Italic

Formatted: Font: Italic

\section{Deleted: static}

Deleted: s 
Special Issue on Disaster Mitigation and Rehabilitation

flow response in terms of both the ESP and $q-\varepsilon_{\mathcal{q}}$ responses, and as indicated by "ABC" in

Fig. 8a-c. The $q_{\text {peak }}$ values of the subsequent 3 cycles were located approximately on the post-QSS strain hardening leg of the corresponding monotonic test.

The second packet of stress pulses consisted of 22 cycles with a prescribed $q_{\text {peak }}$ of $325 \mathrm{kPa}$. This $q_{\text {peak }}$ value was achieved for all 22 cycles despite the first few cycles slightly "overshoot" the corresponding $q-\varepsilon_{\mathrm{q}}$ curves. This is not unexpected because

loading rate for cyclic loading was considerably higher than that of monotonic loading, and that a slight rate effect was likely. Note that the $q_{\text {peak }}$ achieved appeared to drift slightly downwards with number of load cycles. This is because the cyclic loading prescription was based on load and the increase in cross-section area of the specimen led to a slight reduction in deviator stress achieved. It is also interesting to note that the stress-strain loop became "tighter" with load cycles because the corresponding post-QSS $q-\varepsilon_{\mathrm{q}}$ curve was tracing above the prescribed $q_{\text {peak }}$ value.

\subsubsection{Test pair M-00-07 for monotonic loading and C-00-21 for cyclic loading.}

The comparison is presented in Fig. 9a-b, whereas the cyclic load-time trace was plotted in Fig. 9c. The effective stress path (ESP) and deviatoric stress_strain curve of the monotonic test is typical limited flow behaviour, and with rapid post-QSS strain hardening so that the deviator stress at end of test (when $\varepsilon_{\mathrm{q}}=30 \%$.) exceeded $q_{\mathrm{IS}}$.

The specimen for the cyclic test was first sheared to a deviator stress of $q=275$

Formatted: Font: Italic Formatted: Font: Italic Deleted: static

Formatted: Font: Italic

$\mathrm{kPa}$. Then three different packets of stress pulses of different prescribed $q_{\text {peak }}$ values and load cycles were then sequentially applied.

The first packet of stress pulses consisted of 84 cycles with a prescribed $q_{\text {peak }}$ of $275 \mathrm{kPa}$. The ESP traced by this packet of stress pulses traced significantly below the 


\section{Special Issue on Disaster Mitigation and Rehabilitation}

instability line of the corresponding monotonic tests. There was minimal development of pore water pressure or deviatoric strain.

The second packet of stress pulses consisted of 12 cycles with a prescribed $q_{\text {peak }}$ of $405 \mathrm{kPa}$. For the first several cycles of this packet, the ESP did not traced above the instability line (defined by ${ }_{\mathrm{A}} \eta_{\mathrm{IS}}$ of the corresponding monotonic test). The prescribed $q_{\text {peak }}$ value could be developed. However, the development of pore water pressure was more significant compared to the first packet of 84 stress pulses. With further load cycles, the ESP traced across the instability line and development of pore water pressure and deviatoric strain increased rapidly. At point "C" (located above the instability line by a small extent), the prescribed $q_{\text {peak }}$ could not be developed as indicated by "C" and " $\mathrm{C}_{1}$ " of the $q_{\text {peak }}$ developed. The upper limit of the ESP response traced along a curve similar to, but located slightly higher than that of, the downward plummeting leg of the corresponding monotonic tests. Deviatoric strain also developed rapidly. With further development of strain, both the ESP traced beyond the corresponding QSS state of monotonic test M-00-07. The $q_{\text {peak }}$ state climbed back up again along the "upward bend" of the strain hardening leg of the corresponding monotonic tests. It is pertinent to note that when the prescribed deviator stress was located above the instability line, the responses, in terms of both ESP and $q-\varepsilon_{q}$, traced along a "upper limit" curve defined by

Formatted: Font: Italic

Deleted: $\mathrm{t}$

Formatted: Font: Italic

Deleted: the

Formatted: Font: Italic

Formatted: Font: Italic monotonic loading.

The last packet of stress pulses consisted of 12 cycles with a prescribed $q_{\text {peak }}$ of $350 \mathrm{kPa}$. This prescribed $q_{\text {peak }}$ was the deviator stress mobilized at the corresponding strain of the corresponding monotonic test. No sign of instability was observed as indicated by point "D" of Figs. 9b-c. The strain development with load cycles reduced. This is consistent with the prescribed $q_{\text {peak }}$ value being located beneath the post-QSS

Formatted: Font: Italic strain hardening segment of the corresponding monotonic test. 
Special Issue on Disaster Mitigation and Rehabilitation

\subsection{Sand with $15 \%$ fines}

Three test pairs covering the complete spectrum of limited flow behaviour are compared in this sub-section.

\subsubsection{Test pair M-15-05 for monotonic loading and C-15-21 for cyclic loading.}

The comparison is presented in Fig. 10a-b, whereas the cyclic load-time trace was plotted in Fig. 10c. The effective stress path (ESP) and deviatoric stress-strain curve of the monotonic test showed a limited flow behaviour characterized by slight strain hardening after shearing beyond the QSS.

The specimen for the cyclic test was first sheared to a deviator stress from which cyclic loading commenced. Three packets of stress pulses with different prescribed $q_{\text {peak }}$ values were then applied.

The first packet of stress pulses had a prescribed $q_{\text {peak }}$ of $265 \mathrm{kPa}$. A total of 40 cycles were applied. This prescribed $q_{\text {peak }}$ value is higher than the corresponding $q_{\text {IS }}$ of the corresponding monotonic tests (M-15-04). However, the effective stress ratio was less than $\eta_{\mathrm{IS}}$. As shown in Fig. 10a, the ESP traced above that of M-15-04, and the prescribed $g_{\text {peak }}$ was achieved. The overall location of the ESP moved left with each load cycle, but at a rate that reduced with number of load cycles. The stress-strain loops manifested were "tight". This implies instability is not governed by the magnitude of prescribed $g_{\text {peak }}$ relative to $q_{\mathrm{IS}}$

The second packet of stress pulses consisted of 5 load cycles with a prescribed $q_{\text {peak }}$ of $305 \mathrm{kPa}$. This higher $q_{\text {peak }}$ led to higher rate of reduction in $p^{\prime}$, but the stressstrain loops were still "tight", and no instability was observed. It is pertinent to note that the highest stress ratio attained during this 5 load cycles was still less than $\eta_{\mathrm{IS}}$. 
Special Issue on Disaster Mitigation and Rehabilitation

The third packet of stress pulses had a prescribed $q_{\text {peak }}$ of $330 \mathrm{kPa}$. In the first cycle, the prescribed $q_{\text {peak }}$ was achieved at point " $\mathrm{A}$ " (of Figs. 10a \& b) even though the ESP traced above that of M-15-04. At this $q_{\text {peak }}$ value the stress ratio approached $\eta_{\text {IS. }}$ The generation of pore water pressure "pushed" the ESP traced by the second cycle to "point

"B" which was located above the instability line (see Figs $10 \mathrm{a}-\mathrm{b}$ ). The prescribed $q_{\text {peak }}$ could no longer be achieved. The ESP manifested during cyclic loading then traced along a downward plummeting curve "BC" similar to that of M-15-04, although the curve traced by C-15-21 was located above that of monotonic loading. The deviatoric stressstrain curve of segment "BC" for cyclic and monotonic load were almost identical. For the next load cycle beyond point "C", the state of the specimen was beyond QSS. A higher $q_{\text {peak }}$ can be developed as the responses of the specimen traced along the post-QSS strain hardening leg of the corresponding monotonic test.

\subsubsection{Test pair M-15-05 for monotonic loading and C-15-22 for cyclic loading.}

The comparison is presented in Fig. 11a-b, whereas the cyclic load-time trace was plotted in Fig. 11c. The effective stress path (ESP) and deviatoric stress-strain curve of the monotonic test showed a typical limited flow behaviour: significant strain softening followed by significant strain hardening beyond the QSS.

The specimen for the cyclic test was first sheared to a deviator stress of $q=75$ $\mathrm{kPa}$. Then four different packets of stress pulses of different prescribed $q_{\text {peak }}$ values and load cycles were then sequentially applied.

The first packet of stress pulses consisted of 81 load cycles with a prescribed $q_{\text {peak }}$ of $100 \mathrm{kPa}$. This magnitude is significantly less than $q_{\mathrm{IS}}$ of the corresponding monotonic test. As shown in Fig. 11a, the overall location of the ESP moved left with each load cycle, but at a slow rate. The effective stress ratio during all 81 cycles was 


\section{Special Issue on Disaster Mitigation and Rehabilitation}

considerably less than $\eta_{\text {IS }}$. The stress-strain loops did not show any observable hysteresis. There was no indication of instability.

The second packet of stress pulses consisted of 15 load cycles with a prescribed $q_{\text {peak }}$ of $300 \mathrm{kPa}$. This value, although higher than $q_{\mathrm{IS}}$ of the corresponding monotonic tests, could be developed with the first load cycle as indicated by point "A" of Fig. 11a-c. At this stress state, the effective stress ratio was about close to ${ }_{\Delta} \eta_{\mathrm{IS}}$. With the further leftward movement of the ESP (i.e. reduction in $p^{\prime}$ ) associated with cyclic loading, the second cycle crossed the instability line (i.e. achieving an effective stress ratio exceeding $\left.\eta_{\mathrm{IS}}\right)$ and the prescribed $q_{\text {peak }}$ could not be developed as indicated by point "B". The ESP along the loading phase of the cyclic then traced along a curve indicated as " $\mathrm{BC}_{1} \mathrm{C}_{2} \mathrm{C}_{3}$ " in Fig. 11a. It first plummeted towards the origin and then bend upwards as shown in Fig. 11. It followed the upward bend, because the deviatoric strain developed took the specimen beyond the corresponding QSS point. This curve was of a shape similar to that of the corresponding monotonic test.

The third packet of stress pulses consisted of 10 load cycles with a prescribed $g_{\text {peak }}$ of $225 \mathrm{kPa}$. This value was the deviator stress mobilized at point "D" of the corresponding monotonic test. The prescribed $g_{\text {peak }}$ was developed in all 10 cycles. However, the development of $\varepsilon_{\mathrm{q}}$ with each subsequent load cycles was reduced and there was no sign of instability any more.

The last packet of stress pulses consisted of 3 load cycles of increasing prescribed $q_{\text {peak }}$ values of 240,255 , and $270 \mathrm{kPa}$. These $q_{\text {peak }}$ values were estimated from the rate of post-QSS strain hardening of the corresponding monotonic test. The intention was to check whether an increasing $g_{\text {peak }}$ could be developed in line with the post-QSS strain hardening of the corresponding monotonic test. As evident from shown in Fig. 11b-c, these prescribed $g_{\text {peak }}$ values could be developed and there was no sign of instability.

Deleted: had

Formatted: Font: Italic Formatted: Font: Italic Deleted: an

Formatted: Font: Italic

Formatted: Font: Italic 
Special Issue on Disaster Mitigation and Rehabilitation

\subsubsection{Test pair M-15-07 for monotonic loading and C-15-23 for cyclic loading.}

The comparison is presented in Fig. 12a-b, whereas the cyclic load-time trace was plotted in Fig. 12c. The effective stress path (ESP) and deviatoric stress-strain curve of the monotonic loading test (M-15-07) showed a slight strain softening to QSS followed by significant strain hardening.

Cyclic load were applied to test C-15-23 after the specimen was sheared beyond QSS. Thus the responses of the two specimens can be compared over a significant domain. Test C-15-23 manifested more strain softening compared to M-15-07, but the extent of strain softening for this test was still slight. Furthermore, the extent of strain hardening beyond QSS for both tests was significant. As shown in Fig. 12c, five packets

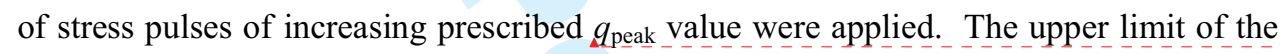

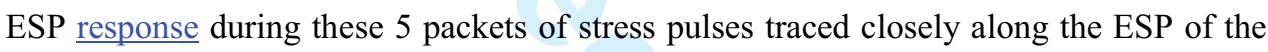
corresponding monotonic test M-15-07. As evident from Fig. 12b, the prescribed deviator stress could be realized, except the first cycle of the first packet as indicated by point "X" which had not clearly past the QSS-point yet. The prescribed $q_{\text {peak }}$ value for the first cycle was below the "corresponding $q-\varepsilon_{\mathrm{q}}$ curve" of the monotonic test. With post-QSS strain hardening, the "corresponding $q-\varepsilon_{\mathrm{q}}$ curve" climbed above the prescribed $q_{\text {peak }}$

Formatted: Font: Italic

Formatted: Font: Italic

Deleted: corresponding

Formatted: Font: Italic

Formatted: Font: Italic

Formatted: Font: Italic

Formatted: Font: Italic

\subsection{Sand with $20 \%$ fines}

The comparison is between test pair M-20-22 for monotonic loading and C-20-20 for cyclic loading. The comparison in terms of ESP and $q-\varepsilon_{\mathrm{q}}$ responses is presented in Fig. 13a-b, whereas the cyclic load-time trace of the cyclic test was plotted in Fig. 13c. The effective stress path (ESP) and deviatoric stress-strain curve of the monotonic loading test 
Special Issue on Disaster Mitigation and Rehabilitation

(M-20-22) showed a significant strain softening to QSS followed by slight strain hardening.

The specimen for cyclic tests C-20-20 was brought to a deviator stress state of $140 \mathrm{kPa}$ and then five packets of stress pulses were applied sequentially. Note that part of the ESP in bringing the specimen to this value appears to be problematic as indicated by "-?-" in Fig. 13a, but these problematic pore water pressure measurements at this early shearing stage has no influence on subsequent interpretation of cyclic response. Furthermore, consistent pore pressure measurement was obtained prior to application of Deleted: However cyclic loading.

The first packet of stress pulses had a prescribed $q_{\text {peak }}$ of $195 \mathrm{kPa}$. This value is less than $q_{\mathrm{IS}}$ of the corresponding monotonic test. Furthermore the effective stress ratio during this packet of stress pulses was always less than $\eta_{\mathrm{IS}}$, the instability stress ratio inferred from M-20-02. The ESP moved slowly to the left with load cycles and the stress-strain loops (Fig. 13b) were tight. There was no sign of instability.

The second packet of stress pulses had a prescribed $q_{\text {peak }}$ of $255 \mathrm{kPa}$, which was higher than $q_{\text {IS }}$ of the monotonic test. However, for the first 4 cycles of this packet, the effective stress ratio was always less than $\eta_{\mathrm{IS}}$ and the prescribed $q_{\text {peak }}$ could still be achieved. The cyclic stress-strain loops were also tight. However, the effective stress path manifested significant leftward movement with load cycles. At the fifth cycle, the ESP just crossed the instability line (as defined by $\eta_{\mathrm{IS}}$ ) of the corresponding monotonic test. It is pertinent to note that the void ratio for this cyclic test is less than that of monotonic test. Thus, one may expect that the cyclic test had to achieve a stress ratio slightly higher than the value of $\eta_{\text {IS }}$ shown in Fig. $13 \mathrm{~b}$ before instability commenced.

Formatted: Font: Italic

Formatted: Font: Italic

Formatted: Font: Italic

Formatted: Font: Italic 
Special Issue on Disaster Mitigation and Rehabilitation

instability line as indicated by point "B". Instability commenced as indicated by the path "BC" which plummeted downward.

The $3^{\text {rd }}$ packet of stress pulses was applied when the response reached point " $X$ " which corresponds to the condition of QSS in monotonic loading. The prescribed $q_{\text {peak }}$ was $100 \mathrm{kPa}$. As indicated by point " $\mathrm{X}$ ", the peak stress attained in first cycle of this packet was slightly below the prescribed $q_{\text {peak }}$, but the prescribed $g_{\text {peak }}$ was attained in subsequent cycles. This is associated with the post-QSS strain hardening behaviour of the corresponding monotonic tests.

The last two packets of stress pulses had a prescribed $q_{\text {peak }}$ of $110 \mathrm{kPa}$ for the $4^{\text {th }}$ packet and $120 \mathrm{kPa}$ for the $5^{\text {th }}$ packet, i.e. the prescribed peak $q_{\text {peak }}$ was of increasing value at a slight rate. The reason was to examine whether the associated strain hardening response of the corresponding monotonic tests could be observed. As evident from Figs. 13b-c, the first cycle of each packet could not attain the prescribed $q_{\text {peak }}$ value. However, the prescribed value was attained in subsequent cycles after the corresponding post-QSS $q-\varepsilon_{\mathrm{q}}$ curve climbed above the prescribed $q_{\text {peak }}$ value. This clearly demonstrated that the slight strain hardening response of the corresponding monotonic test was reflected in the achievable $q_{\text {peak }}$ in cyclic loading.

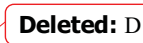

Formatted: Font: Italic

\section{DISCUSSIONS AND CONCLUSION}

An experimental study was conducted to address the issues on limited flow behaviour of sand with fines for a range of fines contents. However, the fines content was always less than the threshold value for the "fines-in-sand" model to be applicable.

The test results showed that, for the complete spectrum of limited flow behaviour, a single set of rules could be used to correlate monotonic and cyclic behaviour for a range of fines content. These rules are presented below. 


\section{Special Issue on Disaster Mitigation and Rehabilitation}

- The onset of instability in cyclic loading is not directly controlled by the magnitude of prescribed peak deviator stress relative to $q_{\mathrm{IS}}$, the deviator stress at onset of strain softening for monotonic loading.

- The criterion for onset of instability during cyclic loading is the development of an effective stress ratio exceeding $\eta_{\mathrm{IS}}$, the instability stress ratio for corresponding monotonic loading. Note that the effective stress ratio during cyclic loading is a function of prescribed peak deviator stress, effective stress state at start of cyclic loading and development of pore water pressure during cyclic loading. The last factor is also a response of the specimen to cyclic loading.

- Once instability commenced, the ESP during the loading phase traced out a curve similar to, but located higher than, the ESP of a corresponding monotonic undrained test. The relationship between the cyclic-peak and cumulative $\varepsilon_{\mathrm{q}}$ traced along a curve similar to that of the corresponding monotonic shearing.

- For cyclic loading applied after shearing beyond the QSS point, the deviator stress that can be developed during cyclic loading is determined by the post-QSS deviatoric stress-strain curve of the corresponding monotonic test. If the prescribed $q_{\text {peak }}$ is less than the deviator stress mobilized at the corresponding $\varepsilon_{\mathrm{q}}$ of a corresponding monotonic test, the prescribed stress can be developed. Otherwise, the deviator stress developed during cyclic loading is bounded by corresponding post-QSS strain hardening segment of a corresponding monotonic test.
Formatted: Font: Italic

Formatted: Font: Italic 
Special Issue on Disaster Mitigation and Rehabilitation

\section{ACKOWLEDGEMENT}

The second author is supported by the Endeavour International Postgraduate Research Scholarship. The last author was supported by the University College Postgraduate Award while conducting his research on instability of sand with fines. The SEM photographs were taken at EMU, Australian National University. The opinions expressed in this paper are, however, solely those of the authors.

\section{LIST OF NOTATIONS}

$q=\sigma_{1}-\sigma_{3}=$ deviator stress

$p^{\prime}=\left(\sigma_{1}^{\prime}+\sigma_{2}^{\prime}+\sigma_{3}^{\prime}\right) / 3=$ effective mean stress

$\varepsilon_{\mathrm{q}}=$ deviatoric strain

$g_{\text {peak }}=$ peak deviator stress in a load cycle (can either be a prescribed value or the resistance provided by the specimen in case of strain softening response)

$\eta=q / p^{\prime}=$ effective stress ratio

Subscript "IS" denotes onset of instability for the corresponding monotonic test. 
Special Issue on Disaster Mitigation and Rehabilitation

\section{REFERENCES}

Bobei, D., 2004. Static Liquefaction of Sand with a Small Amount of Fines. PhD Thesis, University of New South Wales at Australian Defence Force Academy, Canberra, Australia.

Chu, J., and Leong, W. K., 2002. Effect of fines on instability behaviour of loose sand. Géotechnique, 52(10), 751-755.

Chu, J., and Lo, S. R., 1993. On the measurement of critical state parameters of dense granular soils. Geotechnical Testing Journal, 16 (1), 27-35.

Gennaro, V. D., Canou, J., Dupla, J. C., and Benahmed, N., 2004. Influence of loading path on the undrained behaviour of a medium loose sand. Canadian Geotechnical Journal, 41 (1), 166.

Georgiannou, V. N., Hight, D. W., and Burland, J. B., 1991. Behaviour of clayey sands under undrained cyclic triaxial loading. Géotechnique, 41 (3), 383-393.

Konrad, J. M., 1993. Undrained response of loosely compacted sands during monotonic and cyclic compression tests. Géotechnique, 43 (1), 69-89.

Lo, S. R., and Chen, K., 1999. Strain response of granular materials in stress path cyclic triaxial testing. Journal of Transportation Research Record, 66-74.

Lo, S. R., Chu, J., and Lee, I. K. (1989). "A Technique for reducing membrane penetration and bedding errors." Geotechnical Testing Journal, 12(4), 311-316.

Lo, S. R., and Wardani, S. P. R., 2002. Strength and dilatancy of a silt stabilized by cement and fly ash mixture. Canadian Geotechnical Journal, 39 (1), 77.

Mohamad, R., and Dobry, R. 1986. Undrained Monotonic and Cyclic Triaxial Strength of Sand. Journal of Geotechnical Engineering, 112 (10), 941-958.

Rahman, M. M., and Lo, S. R., 2007. Equivalent granular void ratio and state parameters for loose clean sand with small amount of fines. 10th Australia New Zealand Conference on Geomechanics, Brisbane, Australia, 674-679.

Rahman, M. M., and Lo, S. R., 2007. On intergranular void ratio of loose sand with small amount of fines. 16th South East Asian Geotechnical Conference, Kuala Lumpur, Malaysia, 255-260.

Rahman, M. M., and Lo, S. R., 2008. Effect of sand gradation and fines type on the liquefaction behaviour of sand-fines mixtures. 4th decennial Geotechnical 
Special Issue on Disaster Mitigation and Rehabilitation

Earthquake Engineering and Soil Dynamics Conference, GSP-181, ASCE, Sacramento, California, USA.

Rahman, M. M., and Lo, S. R., 2008b. The prediction of equivalent granular steady state line of loose sand with fines. Geomechanics and Geoengineering, 3 (3), 179 190. doi:10.1080/17486020802206867.

Rahman, M. M., Lo, S. R., and Gnanendran, C. T., 2008. On equivalent granular void ratio and steady state behaviour of loose sand with fines. Canadian Geotechnical Journal, 45 (10), 1439-1455. doi:10.1139/T08-064.

Thevanayagam, S., 1998. Effect of fines and confining stress on undrained shear strength of silty sands. Journal of Geotechnical and Geoenvironmental Engineering, 124 (6), 479-491.

Vaid, Y. P., and Sivathayalan, S., 2000. Fundamental factors affecting liquefaction susceptibility of sands. Canadian Geotechnical Journal, 37 (3), 592-606.

Yamamuro, J. A., and Covert, K. M., 2001. Monotonic and Cyclic Liquefaction of Very Loose Sands with High Silt Content. Journal of Geotechnical and Geoenvironmental Engineering, 127 (4), 314-324. 
Special Issue on Disaster Mitigation and Rehabilitation

\section{LIST OF FIGURES}

Fig. 1 Instability under monotonic or cyclic undrained loading

\section{| Fig. 2 Limited flow during undrained loading}

Fig. 3 Grading curves

Fig. 4 SEM photos: a) Host sand; b) Fines;

Fig. 5 Photo of sand with $15 \%$ fines.

| Fig. $6 \quad$ Photo of specimen after loading to $\varepsilon_{\mathrm{q}} \sim 35 \%$

Fig. 7 Testing arrangement (schematic).

Fig. 8 Test pair $\mathrm{M}-00-08$ and $\mathrm{C}-00-20$ for host sand:

a) ESP; b) $q-\varepsilon_{q}$ response; c) stress-time plot

Fig. 9 Test pair $\mathrm{M}-00-07$ and $\mathrm{C}-00-21$ for host sand:
a) ESP; b) $q-\varepsilon_{\mathrm{q}}$ response; c) stress-time plot.

Fig. 10

Test pair $\mathrm{M}-15-05$ and $\mathrm{C}-15-22$ for $15 \%$ fines:

a) ESP; b) $q-\varepsilon_{\mathrm{q}}$ response; c) stress-time plot.

Fig. 11

Fig. 12

Fig. 13

Test pair $\mathrm{M}-15-05$ and $\mathrm{C}-15-22$ for $15 \%$ fines:

a) ESP; b) $q-\varepsilon_{\mathrm{q}}$ response; c) stress-time plot.

Test pair $\mathrm{M}-15-07$ and $\mathrm{C}-15-23$ for $15 \%$ fines:

a) ESP; b) $q-\varepsilon_{\mathrm{q}}$ response; c) stress-time plot.

Test pair $\mathrm{M}-20-02$ and $\mathrm{C}-20-20$ for $20 \%$ fines:

a) ESP; b) $q-\varepsilon_{\mathrm{q}}$ response; c) stress-time plot.

| Table 1. Summary of the testing program (in pairs

\begin{tabular}{|c|c|c|c|c|c|c|}
\hline Test & Test Name & Type & Fines & $\mathrm{e}_{0}$ & $\mathrm{p}_{0}^{\prime}$ & qIS \\
\hline Pair & & $\begin{array}{c}\text { of } \\
\text { loading }\end{array}$ & $\begin{array}{c}\text { content } \\
(\%)\end{array}$ & & $(\mathrm{kPa})$ & $(\mathrm{kPa})$ \\
\hline
\end{tabular}

Deleted: $\mathrm{T}$

Formatted: Font: Italic

Formatted: Font: Italic

Deleted: $T$

Formatted: Font: Italic

Formatted: Font: Italic

Deleted: $\mathrm{T}$

Formatted: Font: Italic

Formatted: Font: Italic

Deleted: $\mathrm{T}$

Formatted: Font: Italic

Formatted: Font: Italic

Deleted: $\mathrm{T}$

Formatted: Font: Italic

Formatted: Font: Italic

Deleted: $T$

Formatted: Font: Italic

Formatted: Font: Italic

Formatted: Font color: Dark Blue 
Special Issue on Disaster Mitigation and Rehabilitation

\begin{tabular}{|c|c|c|c|c|c|c|}
\hline \multirow{2}{*}{1} & C-00-20 & Cyclic & 00 & 0.845 & 600 & - \\
\cline { 2 - 7 } & M-00-08 & Mono & 00 & 0.852 & 600 & 389 \\
\hline \multirow{2}{*}{2} & C-00-21 & Cyclic & 00 & 0.840 & 600 & - \\
\cline { 2 - 7 } & M-00-07 & Mono & 00 & 0.850 & 600 & 355 \\
\hline 3 & C-15-21 & Cyclic & 15 & 0.613 & 600 & - \\
\hline & M-15-04 & Mono & 15 & 0.623 & 600 & 398 \\
\hline 4 & C-15-22 & Cyclic & 15 & 0.625 & 600 & - \\
\hline \multirow{2}{*}{5} & M-15-05 & Mono & 15 & $0.62 \underline{8}$ & 600 & 385 \\
\hline \multirow{2}{*}{5} & C-15-23 & Cyclic & 15 & 0.591 & 600 & - \\
\hline \multirow{2}{*}{6} & M-15-07 & Mono & 15 & 0.588 & 600 & 335 \\
\hline & C-20-20 & Cyclic & 20 & 0.568 & 600 & - \\
\cline { 2 - 7 } & M-20-02 & Mono & 20 & 0.573 & 600 & 394 \\
\hline
\end{tabular}

Formatted: Font color: Dark Blue

Formatted: Font color: Dark Blue

Formatted: Font color: Dark Blue

Formatted: Font color: Dark Blue

Formatted: Font color: Dark Blue

Formatted: Font color: Dark Blue

Where $e_{0}=$ Void ratio after consolidation

$p_{0}^{\prime}=$ Effective mean stress after consolidation

$q_{\mathrm{IS}}=$ Deviatoric stress at instability ratio, $\eta_{\mathrm{IS}}$

Formatted: Font: Italic 
GMGE: Special Issue on Disaster Mitigation and Rehabilitation

\section{LIMITED FLOW BEHAVIOUR OF SAND WITH FINES}

\section{UNDER MONOTONIC AND CYCLIC LOADING}

S.R. LO and MD. MIZANUR RAHMAN

University of New South Wales, ADFA Campus

Canberra, ACT 2600, Australia

D. BOBEI

Sinclair Knight Merz Pty Ltd, Australia 
GMGE: Special Issue on Disaster Mitigation and Rehabilitation

\section{LIST OF FIGURES}

Fig. 1 Instability under monotonic or cyclic undrained loading

| Fig. $2 \quad$ Limited flow during undrained loading

Fig. 3 Grading curves

Fig. 4 SEM photos: a) Host sand; b) Fines;

Fig. 5 Photo of sand with $15 \%$ fines.

| Fig. $6 \quad$ Photo of specimen after loading to $\varepsilon_{\mathrm{q}} \sim 35 \%$

Formatted: Font: Italic

Fig. 7 Testing arrangement (schematic).

Fig. 8 Test pair $\mathrm{M}-00-08$ and C-00-20 for host sand: a) ESP; b) $q-\varepsilon_{\mathrm{q}}$ response; c) stress-time plot.

Fig. 9 Test pair $\mathrm{M}-00-07$ and C-00-21 for host sand: a) ESP; b) $q-\varepsilon_{\mathrm{q}}$ response; c) stress-time plot.

Fig. 10 Test pair $\mathrm{M}-15-05$ and $\mathrm{C}-15-22$ for $15 \%$ fines: a) ESP; b) $q-\varepsilon_{\mathrm{q}}$ response; c) stress-time plot.

Fig. 11 Test pair $\mathrm{M}-15-05$ and $\mathrm{C}-15-22$ for $15 \%$ fines: a) ESP; b) $q-\varepsilon_{\mathrm{q}}$ response; c) stress-time plot.

Fig. 12 Test pair $\mathrm{M}-15-07$ and $\mathrm{C}-15-23$ for $15 \%$ fines: a) ESP; b) $q-\varepsilon_{\mathrm{q}}$ response; c) stress-time plot.

Fig. 13 Test pair $\mathrm{M}-20-02$ and $\mathrm{C}-20-20$ for $20 \%$ fines: a) ESP; b) $q-\varepsilon_{\mathrm{q}}$ response; c) stress-time plot.

\begin{tabular}{|l|}
\hline Deleted: $\mathrm{T}$ \\
\hline Formatted: Font: Italic \\
\hline Formatted: Font: Italic \\
\hline Deleted: $\mathrm{T}$ \\
\hline Formatted: Font: Italic \\
\hline Foleted: $\mathrm{T}$ \\
\hline Formatted: Font: Italic \\
\hline Formatted: Font: Italic \\
\hline Formatted: Font: Italic $\mathrm{T}$ \\
\hline Deleted: $\mathrm{T}$ \\
\hline Formatted: Font: Italic \\
\hline Formatted: Font: Italic \\
\hline Doleted: $\mathrm{T}$ \\
\hline
\end{tabular}


GMGE: Special Issue on Disaster Mitigation and Rehabilitation

Figure 1. Instability under monotonic or cyclic undrained loading

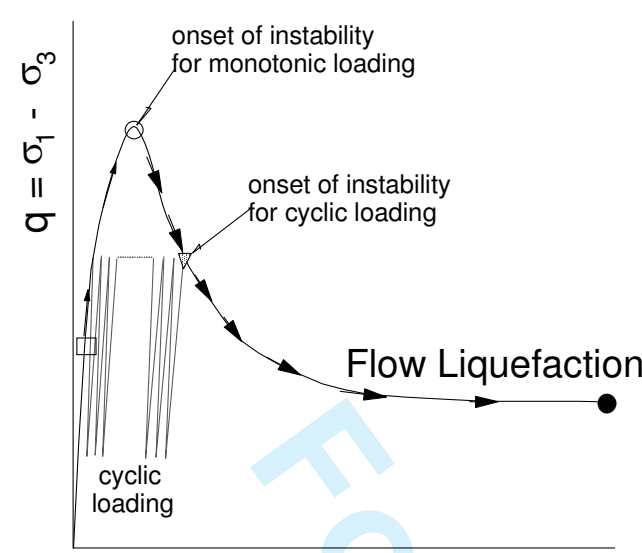

Axial or deviatoric strain

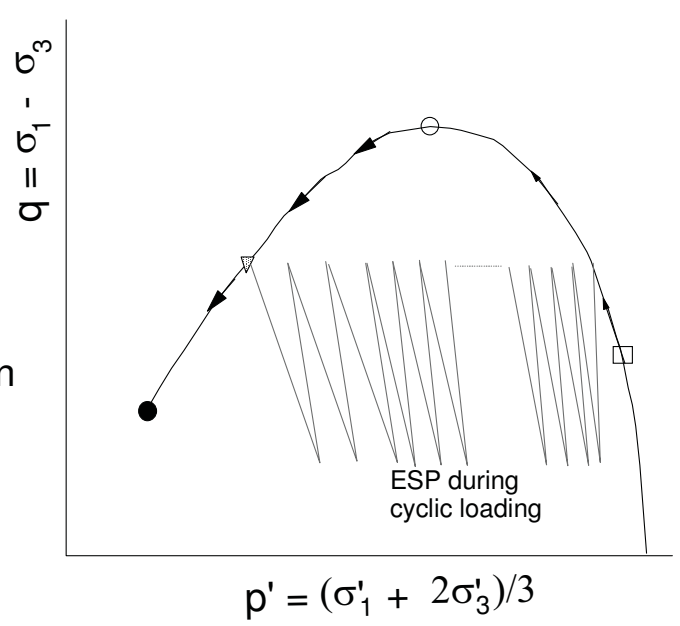


GMGE: Special Issue on Disaster Mitigation and Rehabilitation

Figure 2. Limited flow during undrained loading

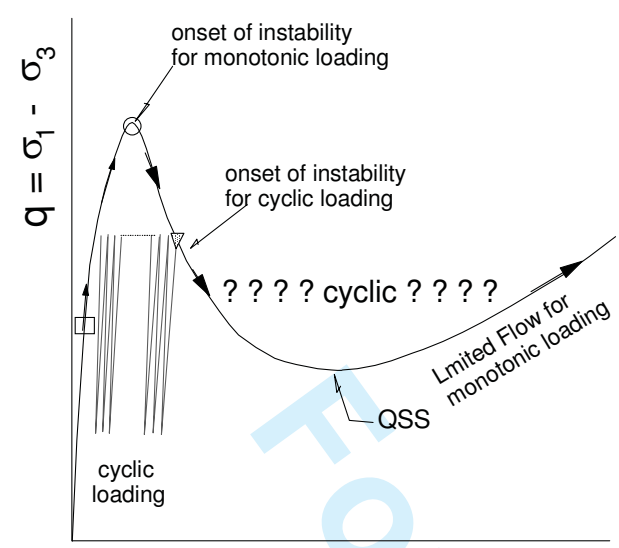

Axial or deviatoric strain

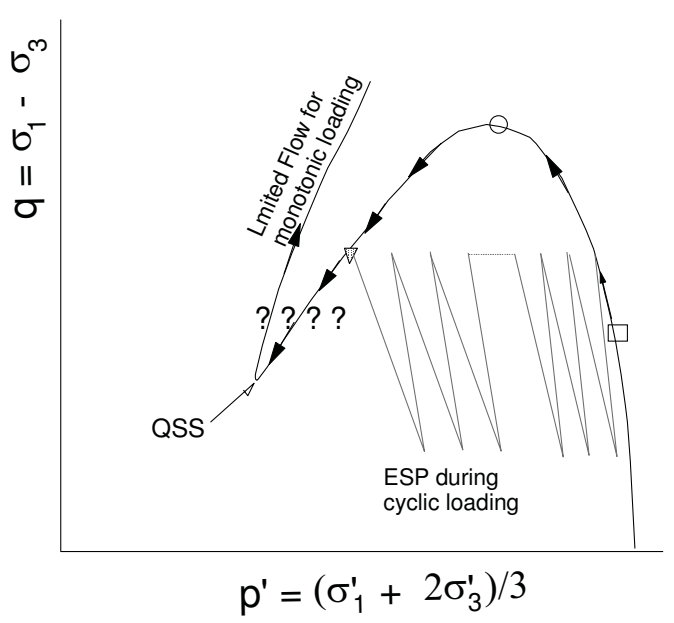


GMGE: Special Issue on Disaster Mitigation and Rehabilitation

Figure 3. Grading curves.

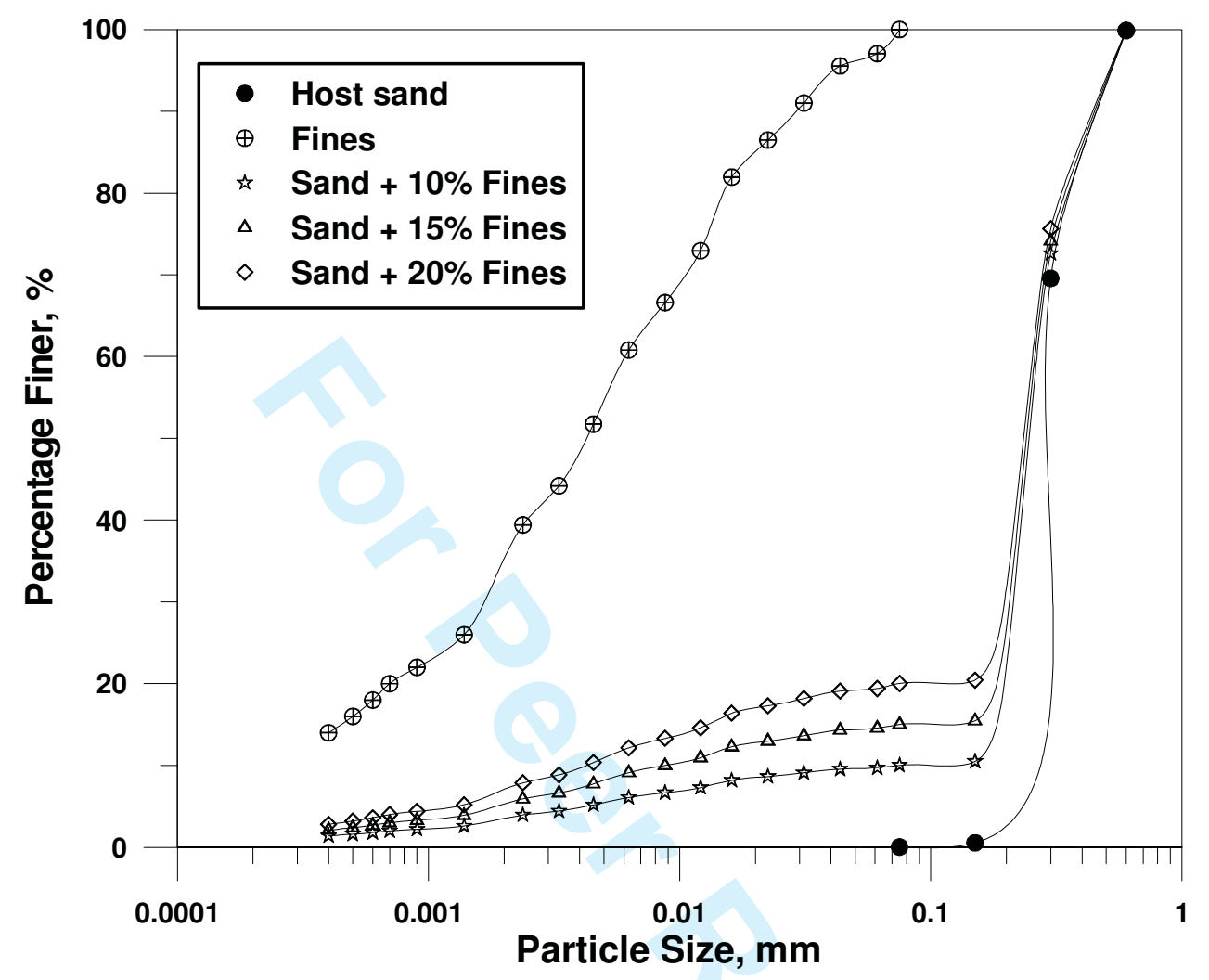


GMGE: Special Issue on Disaster Mitigation and Rehabilitation

Figure 4. SEM photography. (a) Host sand

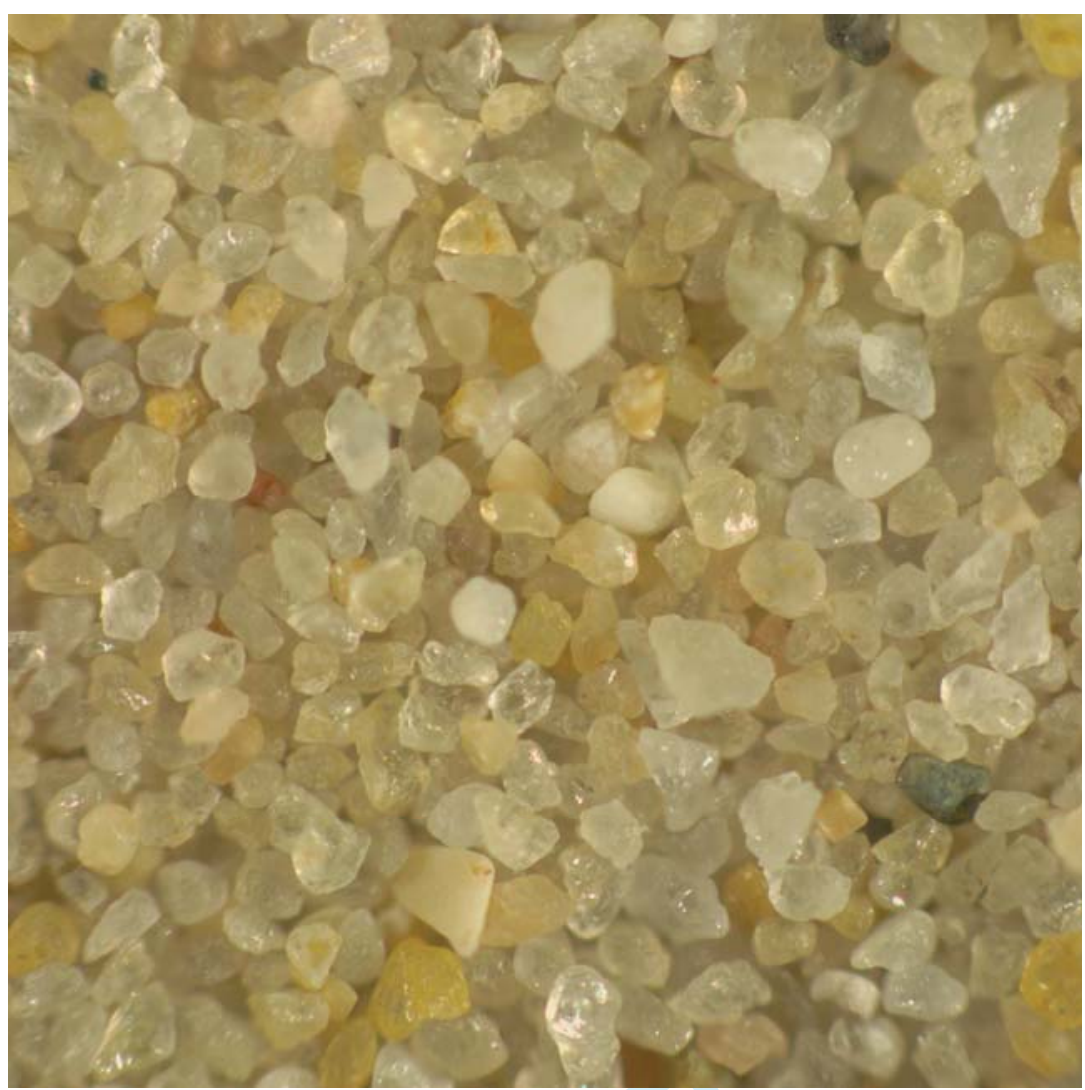


GMGE: Special Issue on Disaster Mitigation and Rehabilitation

Figure 4. SEM photography. (b) Fines

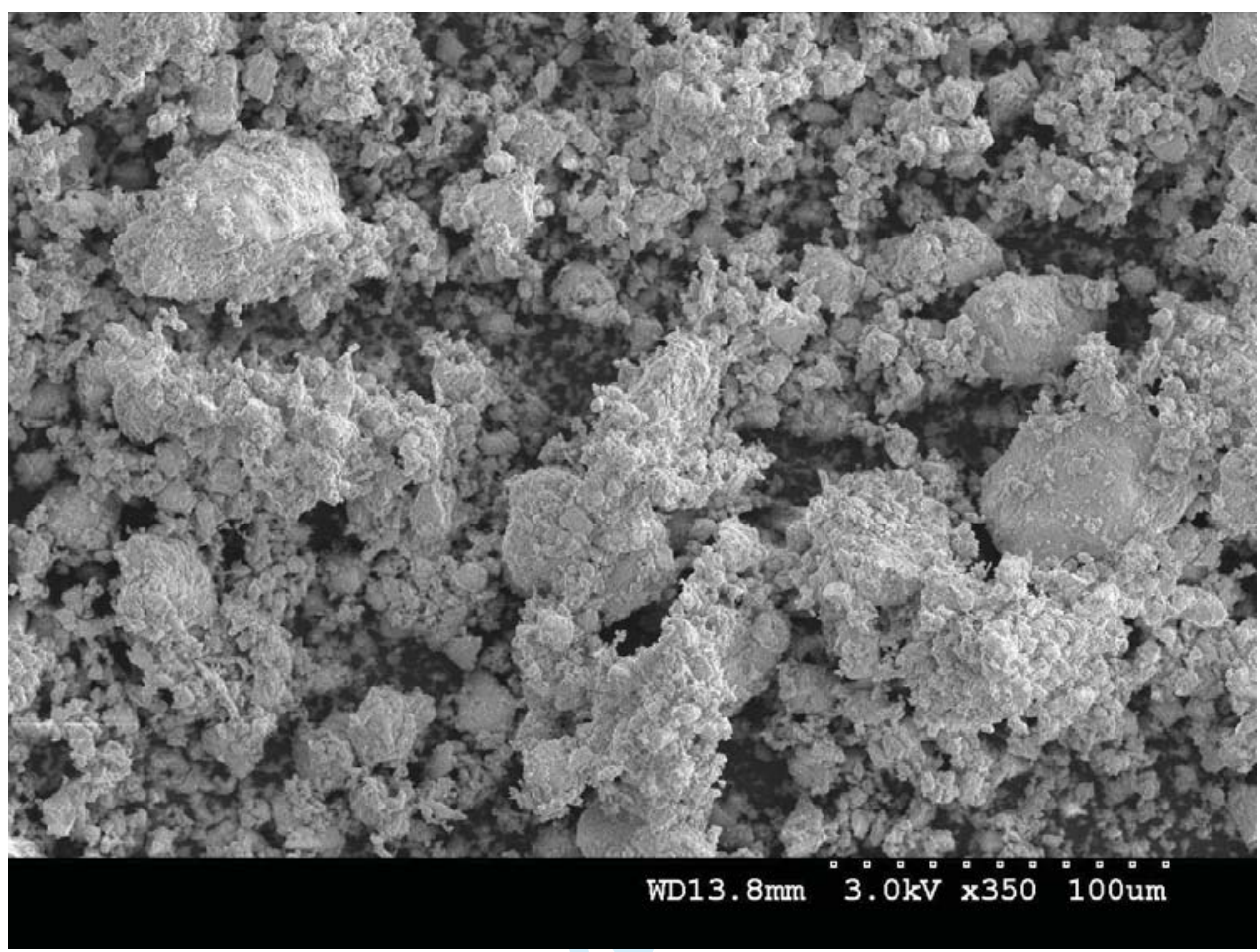


GMGE: Special Issue on Disaster Mitigation and Rehabilitation

Fig. 5. Photo of sand with $15 \%$ fines

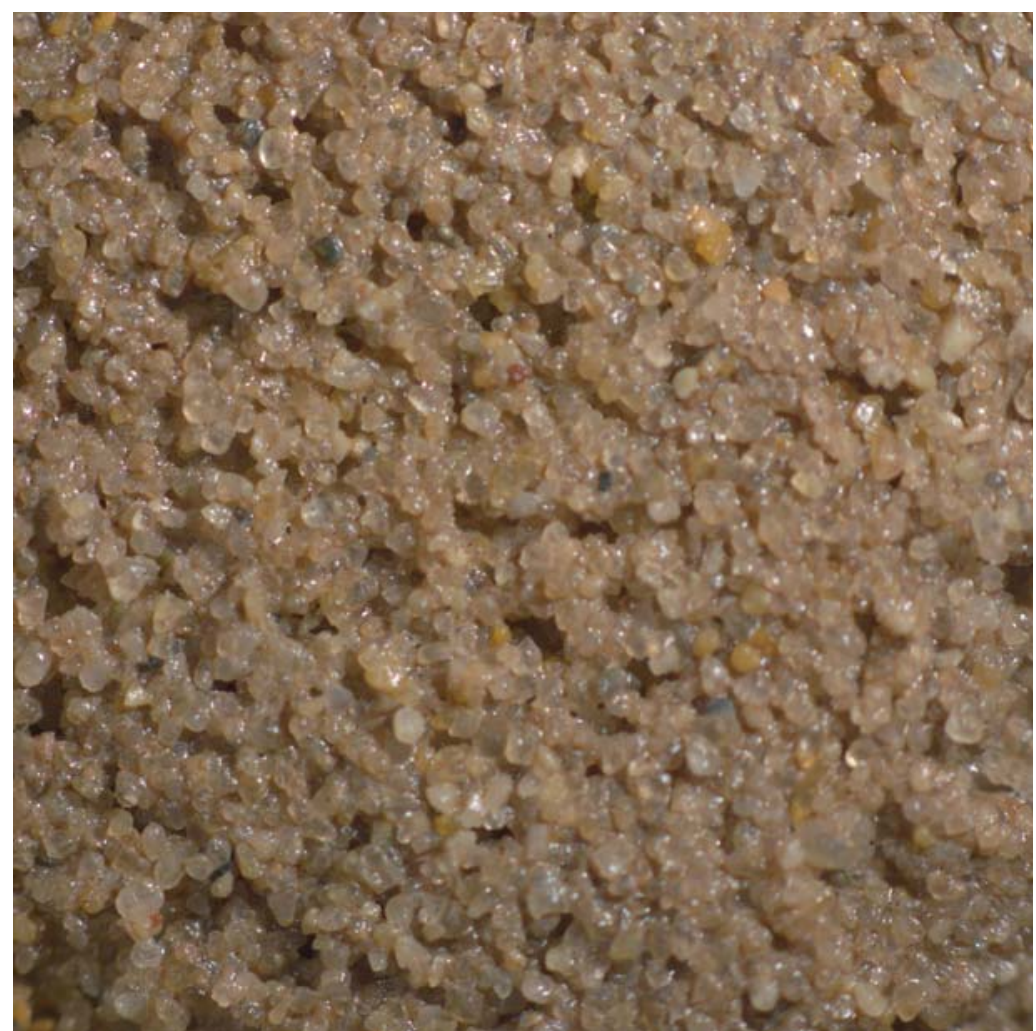


GMGE: Special Issue on Disaster Mitigation and Rehabilitation

| Figure 6. Photo of specimen after loading to $\varepsilon_{\mathrm{q}} \sim 35 \%$

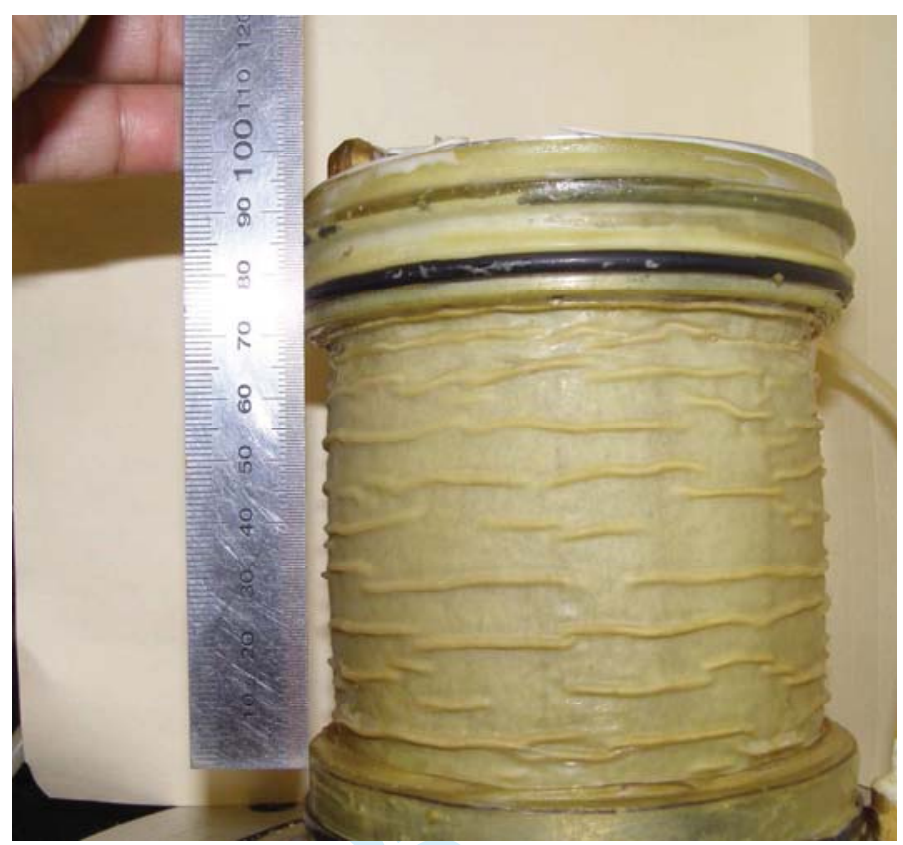


GMGE: Special Issue on Disaster Mitigation and Rehabilitation

Figure 7. Testing arrangement (schematic).

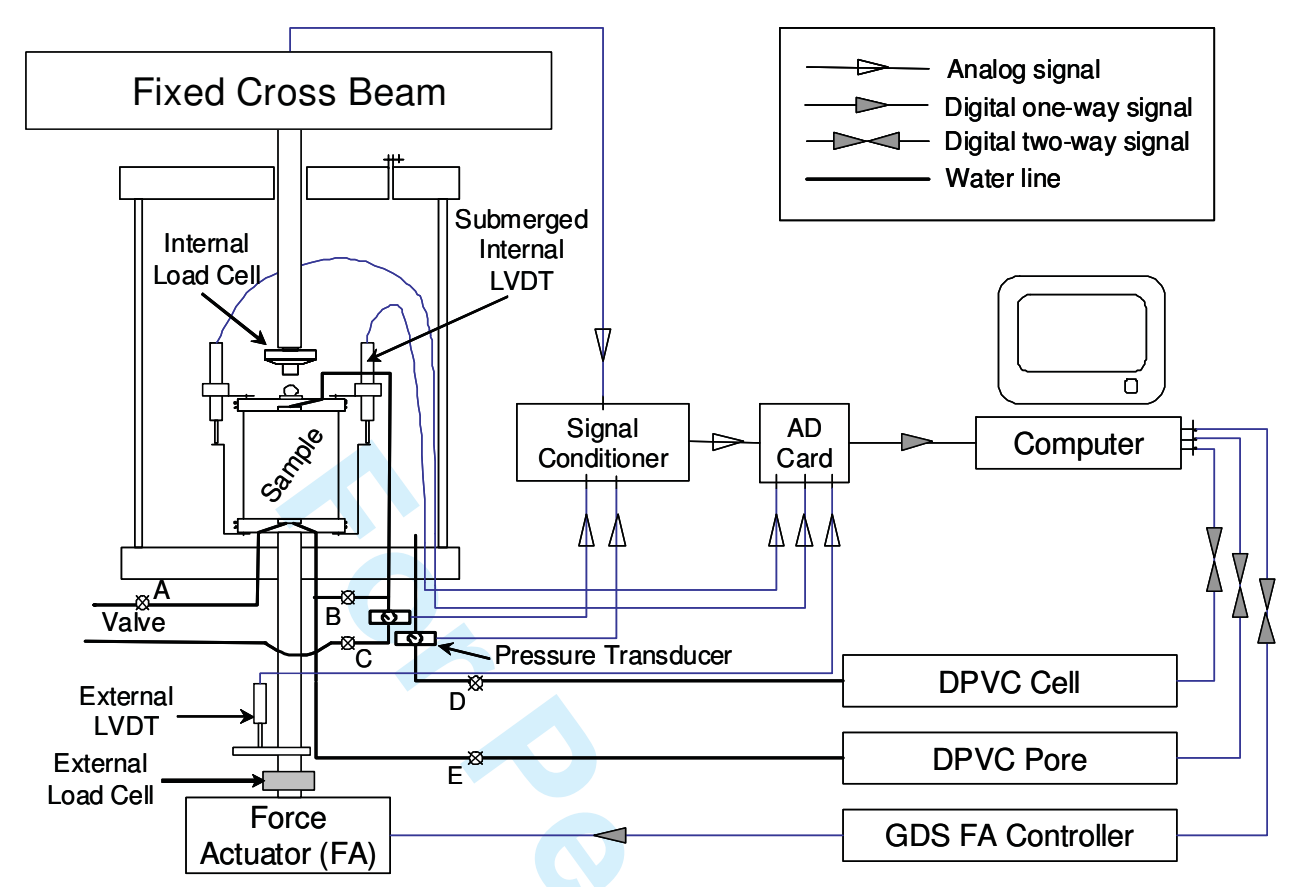


GMGE: Special Issue on Disaster Mitigation and Rehabilitation

Figure 8 . Test pair M-00-08 and C-00-20 for host sand: a) ESP; b) $q-\varepsilon_{\mathrm{q}}$ response; c) stress-time plot.
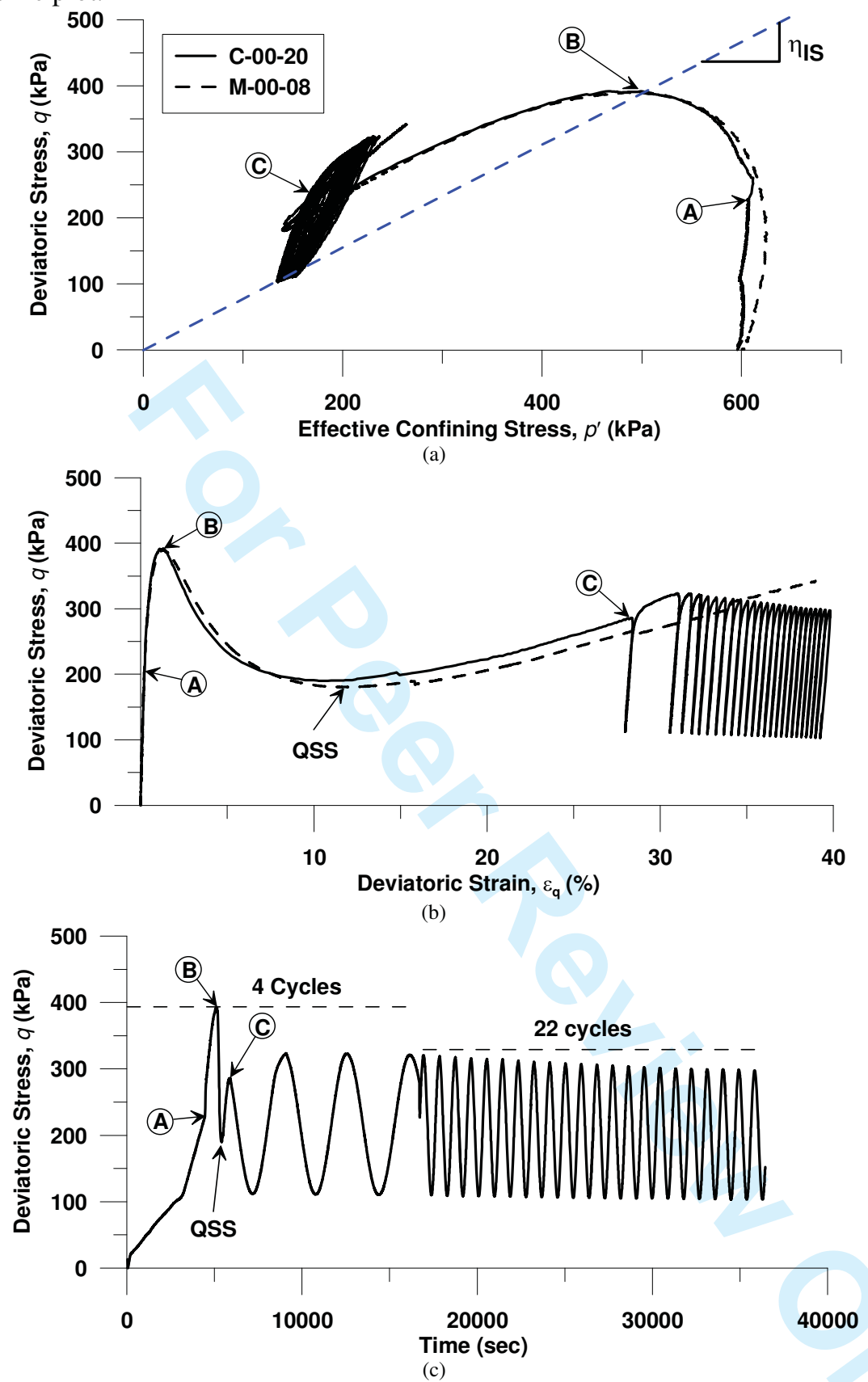
GMGE: Special Issue on Disaster Mitigation and Rehabilitation

Figure 9. Test pair $\mathrm{M}-00-07$ and C-00-21 for host sand: a) ESP; b) $q-\varepsilon_{\mathrm{q}}$ response; c) stress-time plot.

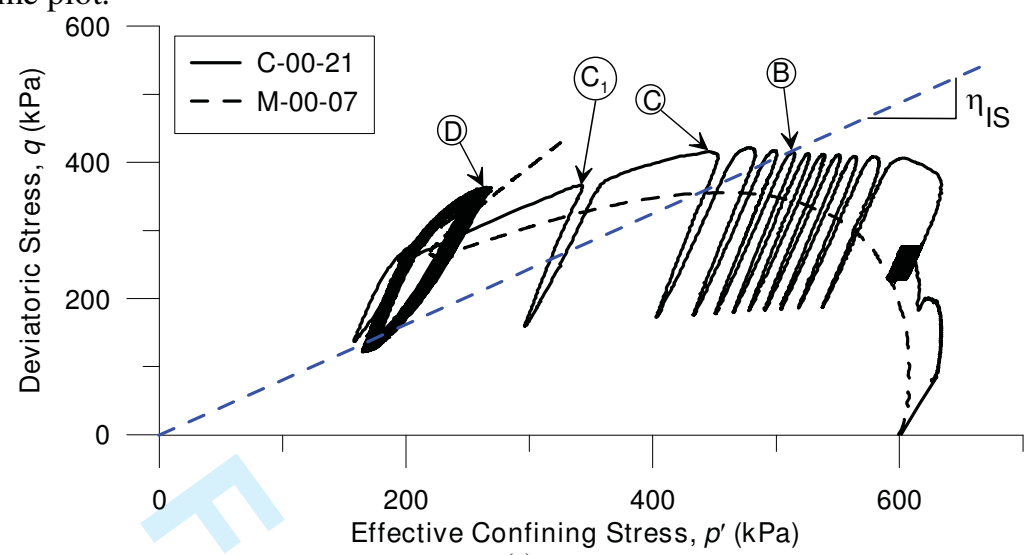

(a)

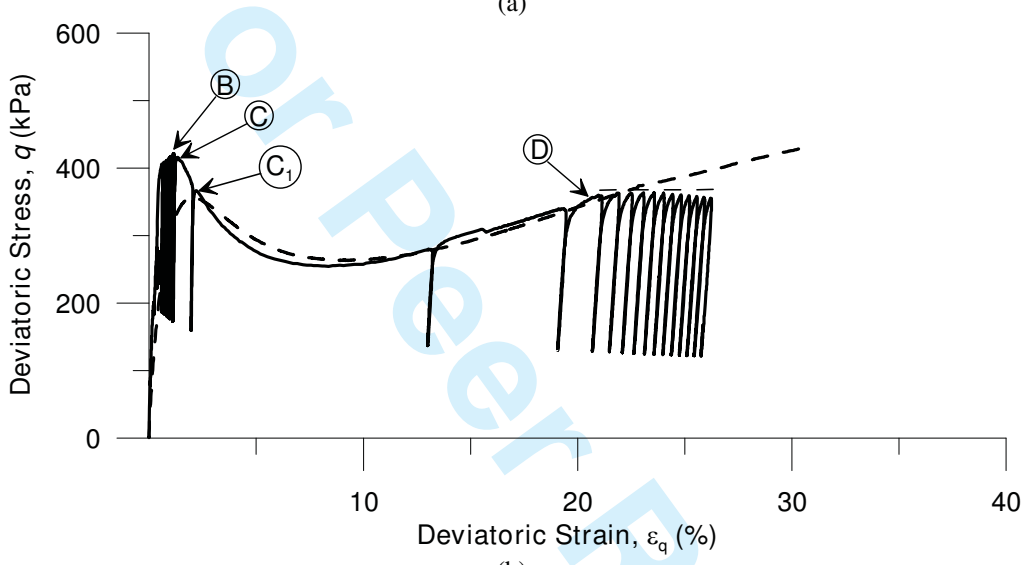

(b)

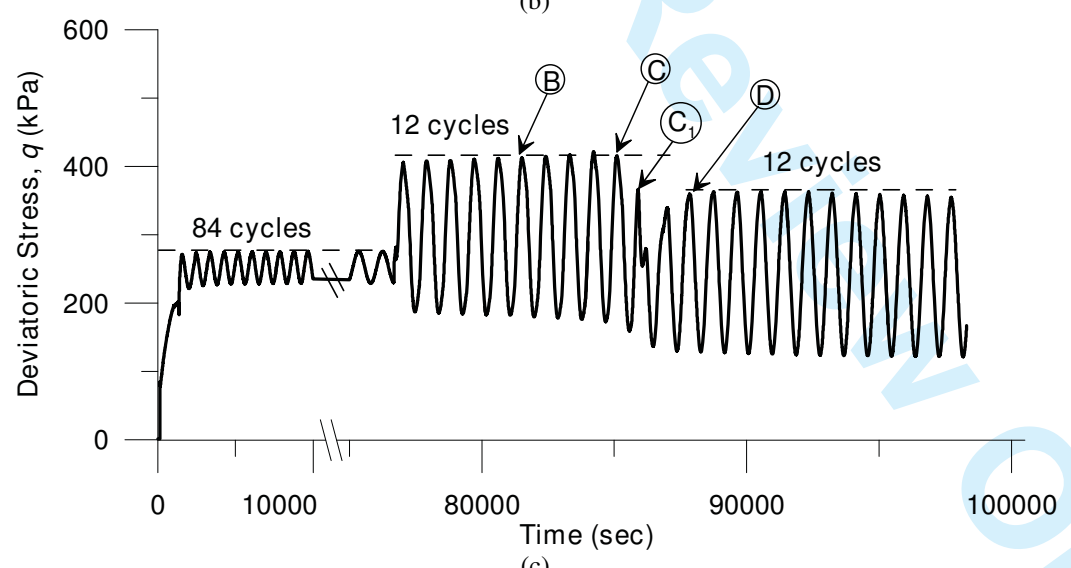

(c)
Deleted: $\mathrm{T}$

Formatted: Font: Italic

Formatted: Font: Italic 
GMGE: Special Issue on Disaster Mitigation and Rehabilitation

Figure 10. Test pair M-15-05 and C-15-21 for 15\% fines: a) ESP; b) $q-\varepsilon_{\mathrm{q}}$ response; c) stress-time plot.

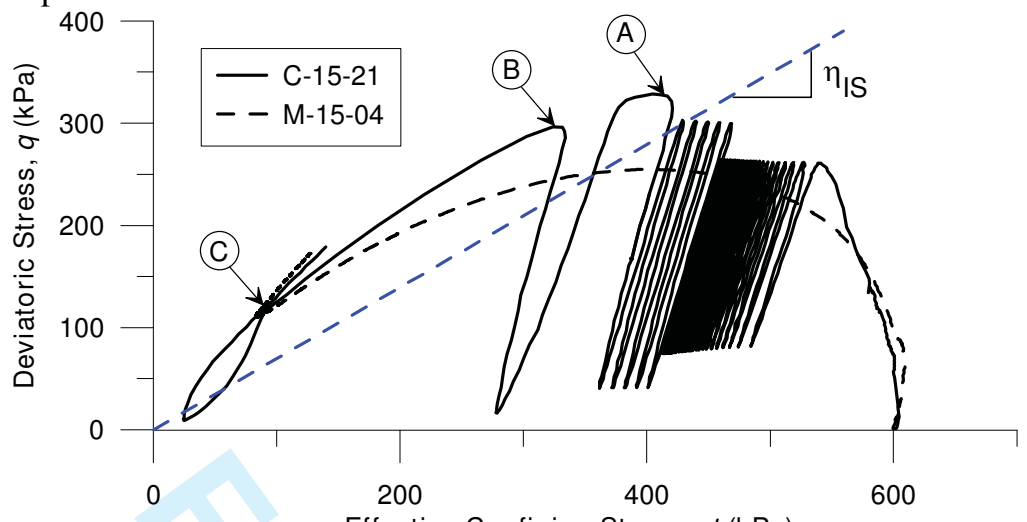

Effective Confining Stress, $p^{\prime}(\mathrm{kPa})$

(a)

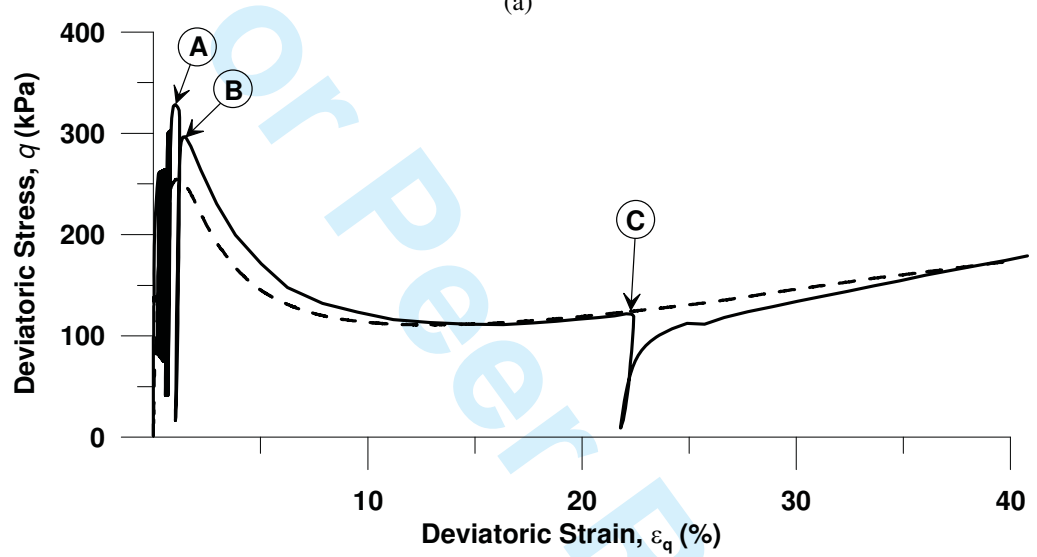

(b)

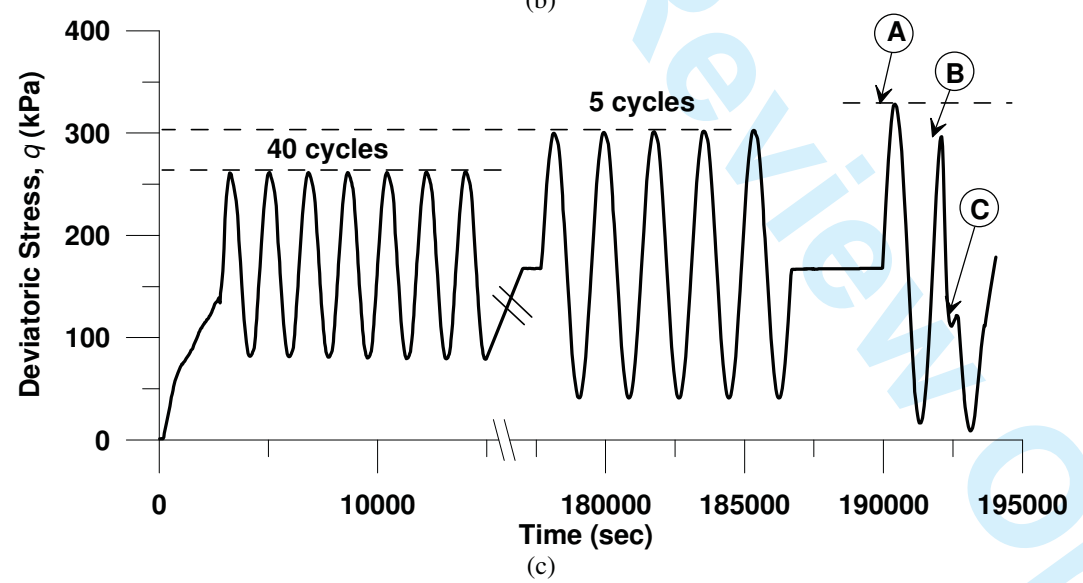


GMGE: Special Issue on Disaster Mitigation and Rehabilitation

Figure 11. Test pair M-15-05 and C-15-22 for $15 \%$ fines: a) ESP; b) $q-\varepsilon_{\mathrm{q}}$ response; c) stress-time plot.

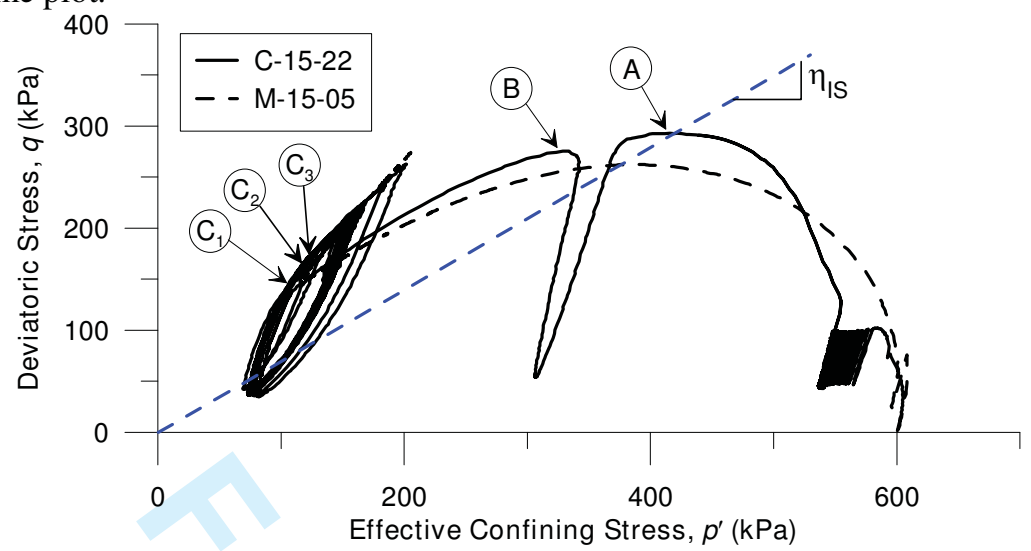

(a)
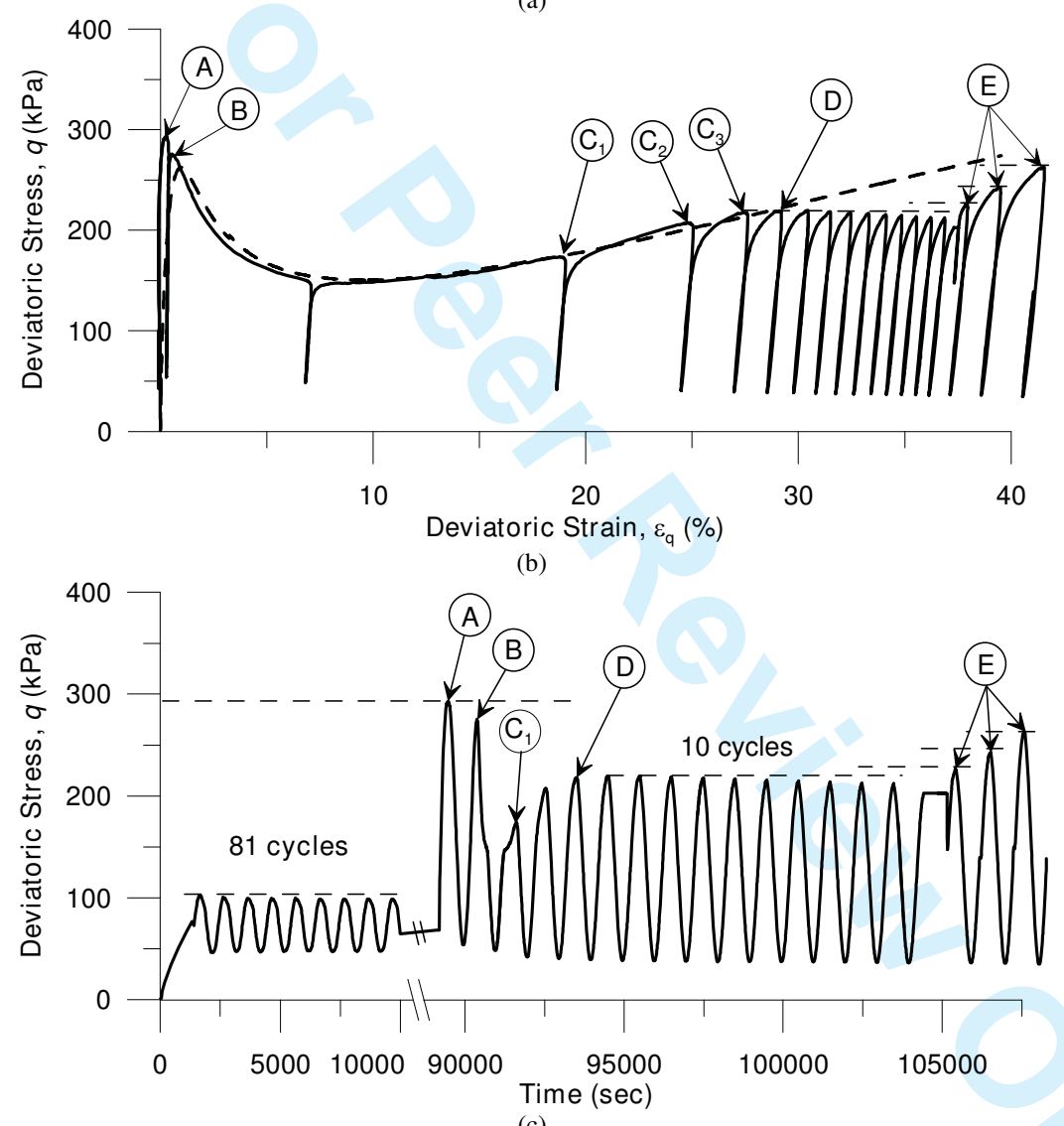

(c) 
GMGE: Special Issue on Disaster Mitigation and Rehabilitation

Figure 12. Test pair M-15-07 and C-15-23 for 15\% fines: a) ESP; b) $q-\varepsilon_{\mathrm{q}}$ response; c) stress-time plot.

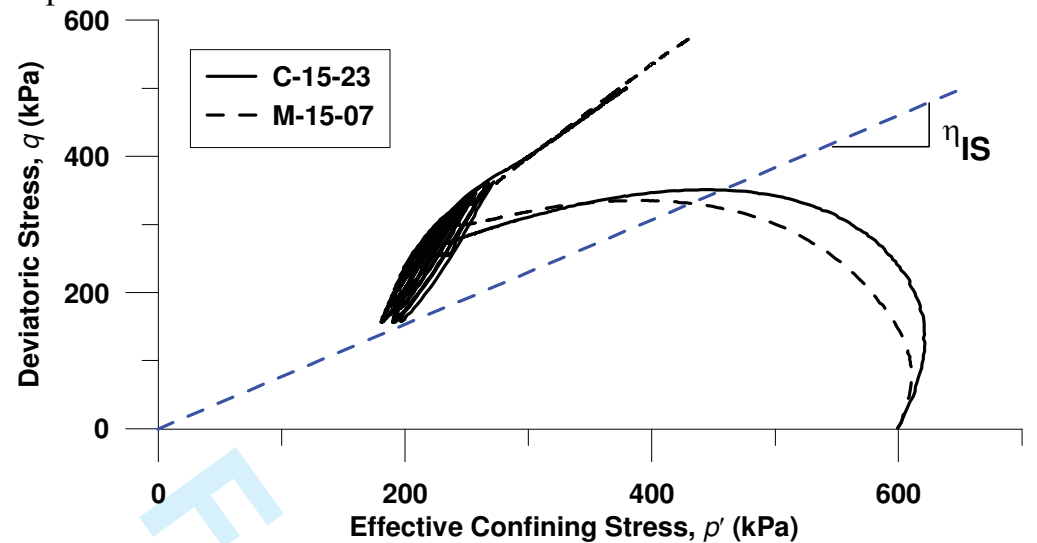

(a)

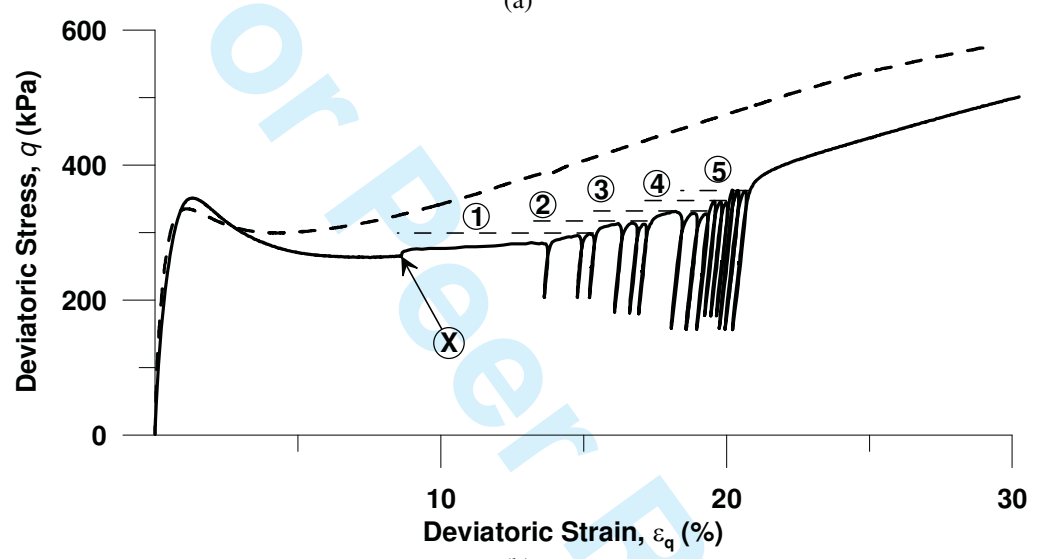

(b)

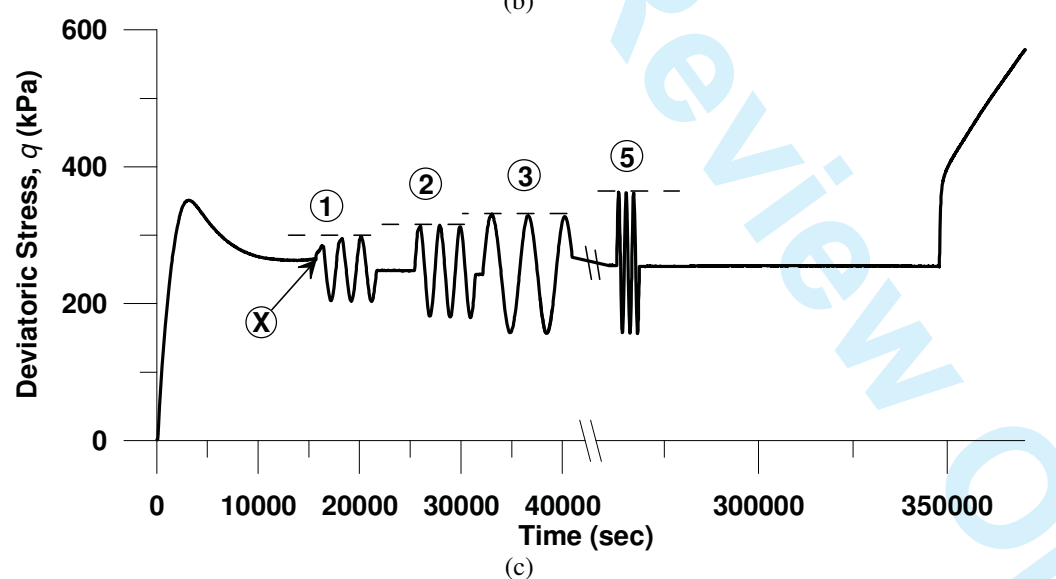


GMGE: Special Issue on Disaster Mitigation and Rehabilitation

Figure 13. Test pair M-20-02 and C-20-20 for 20\% fines: a) ESP; b) $q-\varepsilon_{\mathrm{q}}$ response; c) stress-time plot.

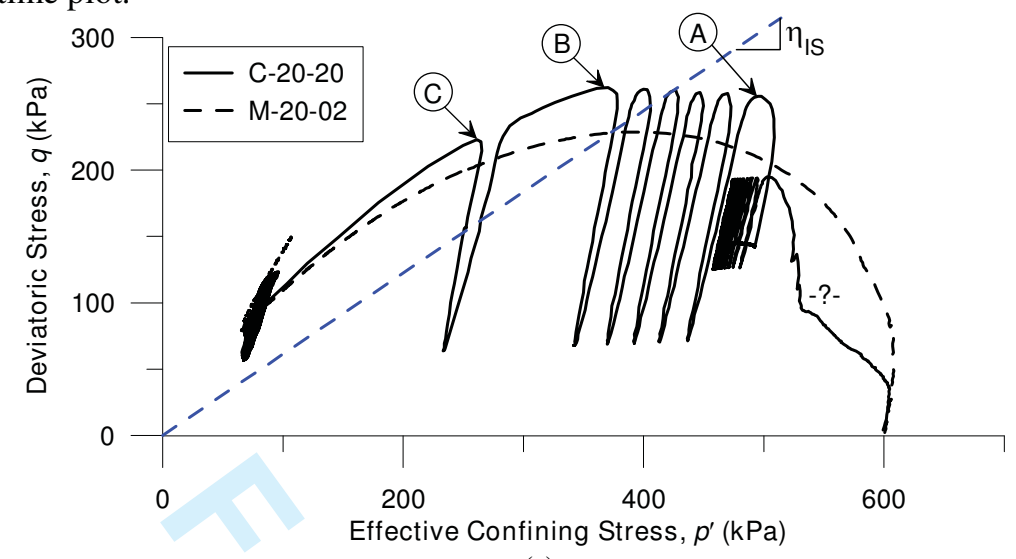

(a)

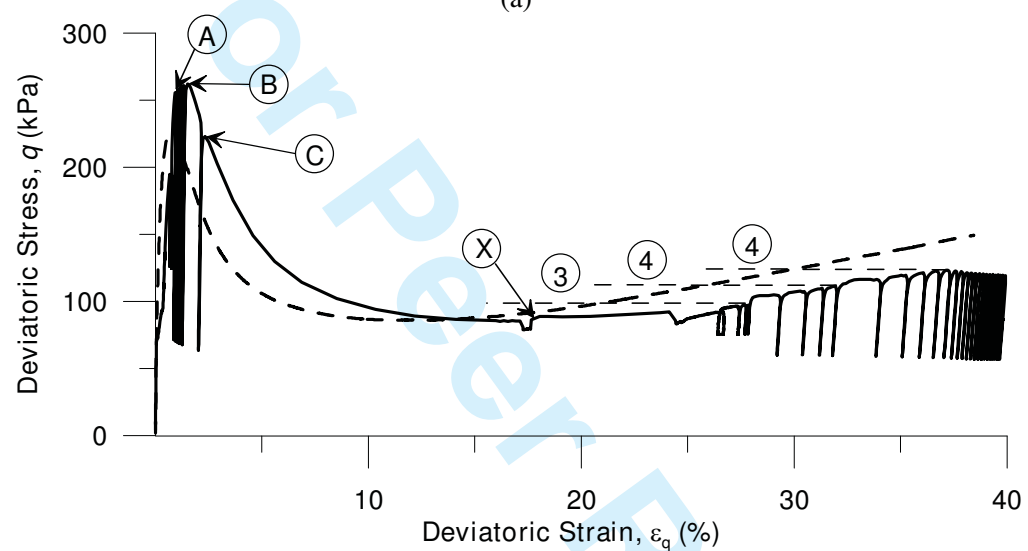

(b)

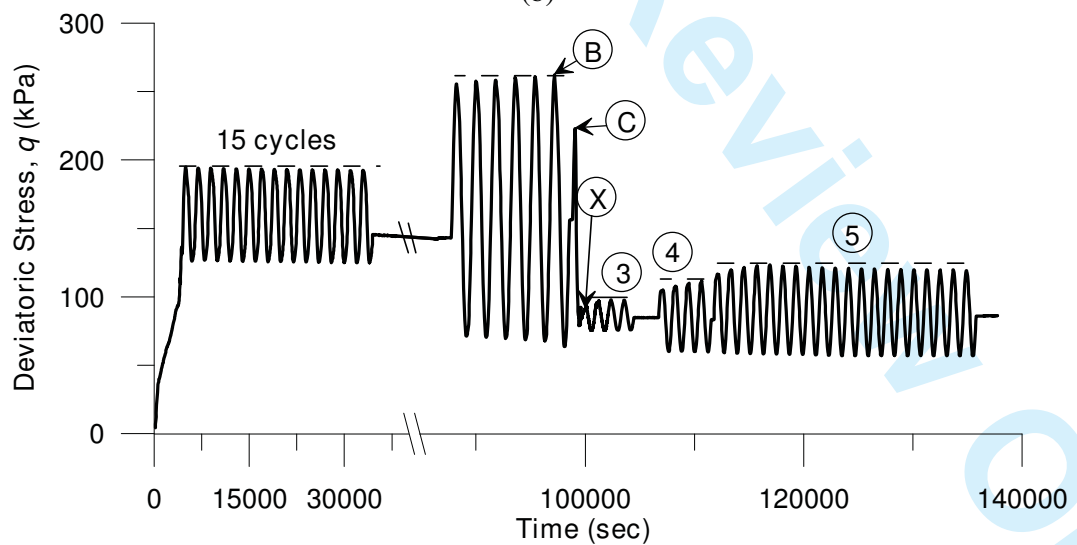

(c) 